In-Conference Workshop - CPAL Interest Group

Digital Information: An Introduction for Librarians and Archivists

1:00-2:00pm

Conversation Groups

e-Books, e-Readers, e-Resources, Oh My! What's a Small Theological Librarian to Do?

\title{
LIBRARY OF CONGRESS' IMPLEMENTATION OF RDA
}

The Library of Congress has set March 31, 2013 as its target for RDA Implementation Day One. Some of LC's partner national libraries (U.S.: National Agricultural Library and National Library of Medicine; and non-U.S.: British Library, Library \& Archives Canada, and National Library of Australia) have targeted the first quarter of 2013.

http://www.loc.gov/catdir/cpso/news rda implementation date.html

\section{TRAINING PRESENTATIONS, WEBCASTS, AND WEBINARS}

Library of Congress Recorded Webcasts for RDA Training

RDA: Looking to the Future: Information Systems and Metadata. Speaker: Barbara Tillett.

Recorded March 9, 2010.

RDA Changes from AACR2 for Texts. Speaker: Barbara B. Tillett. Recorded January 12, 2010. Running time: 75 minutes (41 minutes of presentation followed by Q\&A).

RDA: Recursos Descripción y Acceso: Antecedentes y Aspectos de su Implementación. Speaker: Barbara Tillett. In Spanish. Recorded August 13, 2009. Running time: 85 min.

Georgia Public Library Cataloging Summit http://www.loc.gov/aba/rda/Georgia training aug 2011.html

Library of Congress RDA Training Exercises and Answers http://www.loc.gov/aba/rda/training exercises.html 
RDA Toolkit

Essentials

http://www.rdatoolkit.org/essentials

Association for Library and Technical Services (ALCTS)

ALCTS offers several other webinars and webcasts. Many of the presentations are free.

For more information go to the ALCTS Webinar Archives:

http://www.ala.org/ala/mgrps/divs/alcts/confevents/past/webinar/index.cfm

\section{SELECTED ARTICLES FROM CURRENT LIBRARY JOURNALS}

Barrette, Linda. "Technical Services IS Public Service, or How I Got Out of the Back Room and Why You Should Too.” AALL Spectrum 16, no. 2 (November 2011): 20-22.

Boyd, Morag. "From the Comfort of Your Office: Facilitating Learner-Centered Continuing Education in the Online Environment." Cataloging \& Classification Quarterly 50, no. 2/3 (2012): 189-203.

Gardner, Sue Ann. "Cresting toward the Sea Change: Literature Review of Cataloging and Classification 2009-10.” Library Resources \& Technical Services 56, no. 2 (2012): 64-79.

Garofalo, Denise A. "Useful Web Sites for AV Catalogers.” Technical Services Quarterly 29, no. 2 (2012): 168-170.

Glennan, Kathryn P. "The Development of Resource Description \& Access and its Impact on Music Materials.” Notes 68, no. 3 (March 2012): 526-534.

Hoffman, Gretchen L. "Using the Quality Matters Rubric to Improve Online Cataloging Courses." Cataloging \& Classification Quarterly 50, no. 2/3 (2012): 158-171.

McCutcheon, Sevim. "RDA and the Reference Librarian: What to Expect from the New Cataloging Standard.” Reference Librarian 53, no. 2 (2012): 123-137.

Normore, Lorraine F. “'Here Be Dragons': A Wayfinding Approach to Teaching Cataloguing.” Cataloging \& Classification Quarterly 50, no. 2/3 (2012): 172-188. 